\title{
Navegações ou a descoberta de si
}

\author{
Rodrigo Corrêa Martins Machado*
}

\begin{abstract}
Resumo
Navegações (1983) é um livro, de Sophia de Mello Breyner Andresen, no qual há reflexões acerca de questões e problemas que assolam a história contemporânea de Portugal e a imagem mítica do ser português desbravador. Sendo assim, este trabalho tem como objetivo analisar a obra andreseniana em destaque em contraste com Os Lusíadas, de Luís de Camões. Enquanto o texto camoniano mais se aproxima de uma epopeia tradicional, marcado pela viagem marítima em barcos, com herói, uma narração, uma glorificação, Navegações pode ser considerada uma epopeia moderna, em que o sujeito poético, sobrevoando o globo em um avião, questiona o país, a vida e o presente em que vive.

Palavras-Chave: Navegações. Os Lusíadas. Camões. Sophia de Mello Breyner Andresen.
\end{abstract}

\section{Navigations or The Self-Discovery}

\begin{abstract}
Navegações (1983) is a book, by Sophia Andresen, in which there are reflections on issues and problems facing the contemporary history of Portugal and the mythical image of the pioneering Portuguese. Therefore, this study aims to analyze the Andresenian work in contrast to Os Lusíadas, by Luis de Camões. While the Camonian text comes closer to a traditional epopee, marked by maritime voyage in boats with a hero, a narrative, a glorification, Navegações can be considered a modern epopee, in which the poetic subject, circling the globe in an airplane, questions the country, and the life that he lives there.
\end{abstract}

Keywords: Navegações. Os Lusíadas. Camões. Sophia de Mello Breyner Andresen.

* Universidade Federal de Ouro Preto (UFOP). Doutor em Literatura Comparada pela Universidade Federal Fluminense. Professor Adjunto do Departamento de Letras da Universidade Federal de Ouro Preto 


\title{
1 Navegação pela tradição marítima da literatura portuguesa
}

\author{
Navegação \\ Distância da distância derivada \\ Aparição do mundo: a terra escorre \\ Pelos olhos que a vêem revelada. \\ E atrás um outro longe imenso morre \\ (ANDRESEN, 2011, p. 105)
}

Com os versos acima, inicio o percurso pelas Navegações andresenianas (ANDRESEN, 1983) que, já no título, enceta de imediato seu lugar na tradição marítima da literatura portuguesa. Como é passível de ser notado, esse tema, recorrente e prezado pela autora, já fazia eco em sua poesia desde os primeiros poemas publicados, nos quais a temática marítima se fez predominantemente presente, muito menos enquanto glorificação pátria do que uma maneira de (re)pensar o desajustamento do cidadão português diante de uma realidade que se sabe estilhaçada.

Desde o início da leitura de Navegações fica patente que essa obra advoga seu lugar na cena literária portuguesa enquanto uma composição artística literária que se aparelhe a Os Lusíadas camonianos. Na moderna viagem empreendida por Sophia Andresen, ela vai de avião, a sobrevoar o oriente para, a partir das impressões feitas de cima, repensar a condição portuguesa no século XX. Como é destacado pela própria autora:

Corri uma cortina e vi um ar fulgurantemente azul e lá em baixo um mar ainda mais azul. E, perto de uma longa costa verde, vi no mar três ilhas de coral azul-escuro cercadas por lagunas de uma transparência azulada. Pensei naqueles que ali chegaram sem aviso prévio, sem mapas, ou relatos, ou desenhos ou fotografias que os prevenissem do que iam ver (ANDRESEN, 2011, p. 699).

No que diz respeito ao intertexto entre a obra andreseniana e a camoniana, evoco aqui Jorge Fernandes da Silveira (2000) a revelar que a literatura nacional lusitana é uma tentativa de se fazer arte escrita após Os Lusíadas. Sendo assim, não seria a obra andreseniana em questão uma nova epopeia fundadora? Nesse caso, pode tratar-se de uma epopeia fundadora da consciência de pequenez que não foi estabelecida na mente dos nascidos em Portugal. Tema esse sempre em voga nos escritos poéticos pós-Revolução dos Cravos.

Eduardo Lourenço em O Labirinto da Saudade [...] (2000, p. 25) ressalta que em terras portuguesas tanto o complexo de inferioridade quanto o de superioridade tem a função única de esconder dos cidadãos a "[...] autêntica situação de ser histórico em estado de intrínseca fragilidade". Talvez, por ser uma pequena nação que se recusou sempre a reconhecer seus limites, Portugal (e seus habitantes) necessitam da literatura enquanto um meio psicanalítico de análise interior, enquanto um mecanismo que abale as concepções pré-estabelecidas, colocando todos diante da (cruel) realidade. Sendo assim, enquanto Os Lusíadas de Camões evoca "o peito ilustre lusitano/ a quem Netuno e Marte obedeceram" (Lus., I, 3: 18), as Navegações andresenianas destacam a extinção "em nós memória e tempo" a que "o mar devorou com instinto de destino [...]",e "Lisboa cruelmente construída ao longo da sua própria ausência".( ANDRESEN, 1983, p. s/n)

Esses versos destacados dão a tônica deste trabalho e do diálogo que desejo estabelecer entre a obra andreseniana e a camoniana. Os pontos de contato entre essas duas grandes obras da literatura portuguesa são bem mais extensos e têm início com o mote que, segundo Sophia, teria dado origem à sua obra: uma viagem a Macau para comemorar o Dia de Camões. Nas palavras da própria poeta: "Escrevi Navegações exatamente porque o conselho da Revolução, em 1977 me convidou a ir a Macau para tomar parte na celebração do Dia de Camões. Foi meu primeiro contato com o oriente" 
(ANDRESEN,2011, p. 699). E será mesmo o primeiro contato com o oriente que teve a autora? Mesmo que seja num plano metafísico, cultural e histórico, os portugueses em geral nascem com a tatuagem do oriente cravada na pele, uma vez que toda a grandeza histórica cultuada por séculos, desbravamentos, crescimentos de Portugal têm origem na busca de uma rota marítima para a Índia. E é exatamente essa mesma rota que liga, nesse instante, as duas obras destacadas neste trabalho.

\section{Camões e Sophia, navegantes portugueses}

Se Camões canta o encanto do descobrimento de um mundo novo, da difusão do catolicismo e possibilidade de expansão econômica (muitas vezes de maneira crítica, certamente), Sophia traz à tona a beleza do oriente, os espasmos que esse continente causa ao ser visto pela primeira vez, como também todas as consequências negativas que as navegações para as Índias trouxeram para a pequena casa lusitana. Conforme Sofia Sousa Silva (2010, p. 125), "É precisamente a visualidade e a capacidade de fazer surgir um mundo que Sophia valoriza na épica camoniana e que homenageia nas suas próprias Navegações”.

É necessário enfatizarmos que os poemas que compõem a obra andreseniana destacada foram escritos no período de 1977 a 1982. Isso nos remete ao fato de que, historicamente, a Revolução dos Cravos, a partir de 1975, já havia tomado rumos inesperados por aqueles que dela ansiavam verdadeiras mudanças políticas, econômicas e sociais em Portugal. Dentre esses rumos inesperados, cabe destacar que a partir de 1975, além de tornar-se economicamente dependente dos Estados Unidos da América e da Alemanha Ocidental (cf. SECCO, 2004) - o que afastou o levante de abril de seus objetivos socialistas - Portugal também iniciou a receber os retornados das ex-colônias lusitanas na África. Como apontado por Keneth Maxwell (2006, p. 198), "Portugal entrou no inverno de 1975 com aproximadamente 400 mil desempregados, dos quais apenas 19 mil recebiam algum tipo de seguro social. E, para rematar, cerca de 500 mil pessoas estavam voltando de Angola, em sua maioria destituídas, pois seu dinheiro perdera valor".

A “pequena casa lusitana" dependente economicamente dos grandes impérios capitalistas mundiais, observando o aumento considerável de uma crise sociopolítica anunciada, acaba por tomar caminhos capitalistas e democráticos. Ao mesmo tempo, para assegurar uma reforma econômica mais sólida foi necessário que os políticos portugueses recorressem à Comunidade Europeia, demarcando assim, sua dependência das grandes potências da Europa. Essa dependência econômica levou Portugal a ingressar na União Europeia em 1986, tornando, de certa forma, irreversíveis as concretizações dos ideais difundidos na aurora de 25 de abril de 1974. Ao se dobrar ao jugo capitalista e europeu, demarcou-se um lugar de marginalização continental para a pátria portuguesa.

É certo que, sabedora da situação econômica, política e social portuguesa, sendo uma poeta e cidadã politicamente ativa, Sophia Andresen escreve Navegações. Como apontado por Rodrigo Machado (2012), já na terceira parte de "O Nome das Coisas", a poeta revela um desencantamento com os desdobramentos da Revolução de Abril e com os rumos que o país toma após 1974 - "Do quebrado projecto de sua empresa em ruína/canto e pranto clamor palavras harpas" (ANDRESEN, 1977, p. 58) -, bem como a consciência crítica de que alguns sonhos não mais se concretizarão, como bem revelam os versos de "Poema": "Cantaremos o desencontro:/O limiar e o linear perdidos//Cantaremos o desencontro:/A vida errada num país errado/Novos ratos mostram a sua cara”(ANDRESEN, 1977, p. 75).

Logo, Navegações, obra lançada após quase dez anos da Revolução dos Cravos, não pode ser um livro de encantamento perante um mundo que se afigurou um dia como algo a ser desbravado e conquistado, senão um dado melancólico acerca de tudo aquilo que Portugal poderia ter sido, mas não 
foi - algo assinalado (e dialogado com) por Fernando Pessoa na última estrofe do poema "O Infante", na qual ele abaliza "Quem te sagrou creou-te portuguez./ Do mar e em ti nos deu signal./ Cumpriu-se o Mar, e o Imperio se desfez./ Senhor, falta cumprir-se Portugal!” (PESSOA, 2007, p.78).

Portugal não se cumpre, nem mesmo após a Revolução que, inicialmente, tinha uma aura libertadora e expurgadora dos males da história e, principalmente, da ditadura. Estou de acordo com Luis Maffei (2012, p. 111), quando ele sublinha o caráter crítico e reflexivo de Navegações, uma vez que esta obra foi elaborada em uma época "[...] em que navegar, historicamente, é retornar, é fazer parte, portanto, de uma nau menos gloriosa que as gloriosas e soturna como de As Naus [em referência à obra de António Lobo Antunes]”.

Muitos estudiosos dos escritos de Sophia Andresen veem Navegações enquanto um livro no qual se está diante do maravilhamento e espanto da poeta frente ao Oriente. Entretanto, a leitura que empreendo desta obra espantosa vislumbra ali um canto melancólico de um presente cruel, soturno, que deve suas desgraças à má administração pública, a ditadura salazarista, não se esquecendo de fatos ulteriores que marcaram a vida de todo português como a megalomania dos desbravamentos levados a cabo no séculos XV e XVI. A meu ver, Sophia revisita a epopeia camoniana e constrói a sua de maneira tão crítica quanto Antero de Quental o fez em 27 de maio de 1871 com a conferência "Causas da decadência dos povos peninsulares nos últimos três séculos" ou de outros pensadores contemporâneos como Eduardo Lourenço, José Gil e Boaventura de Sousa Santos, entre outros.

\section{Navegações: uma epopeia moderna}

Seguindo os preceitos de Virgínia Boechat (2004) ao notar que Navegações é uma epopeia da Era Moderna, que pode ser dividida em três partes: a primeira com início no poema "Lisboa", a segunda em "As ilhas" e a terceira em "Deriva", opto por ler neste trabalho poemas que marcam as divisões da obra.

Em um primeiro momento, é possível de partida observar que a parte primeira ("Lisboa") pode ser equiparada a uma espécie de proposição épica (informação verbal) ${ }^{2}$, na qual introduz-se a obra, os poemas, apresenta-se a matéria a ser abordada e, de certa maneira, postulam-se os heróis a serem (re) visitados - a nação portuguesa:

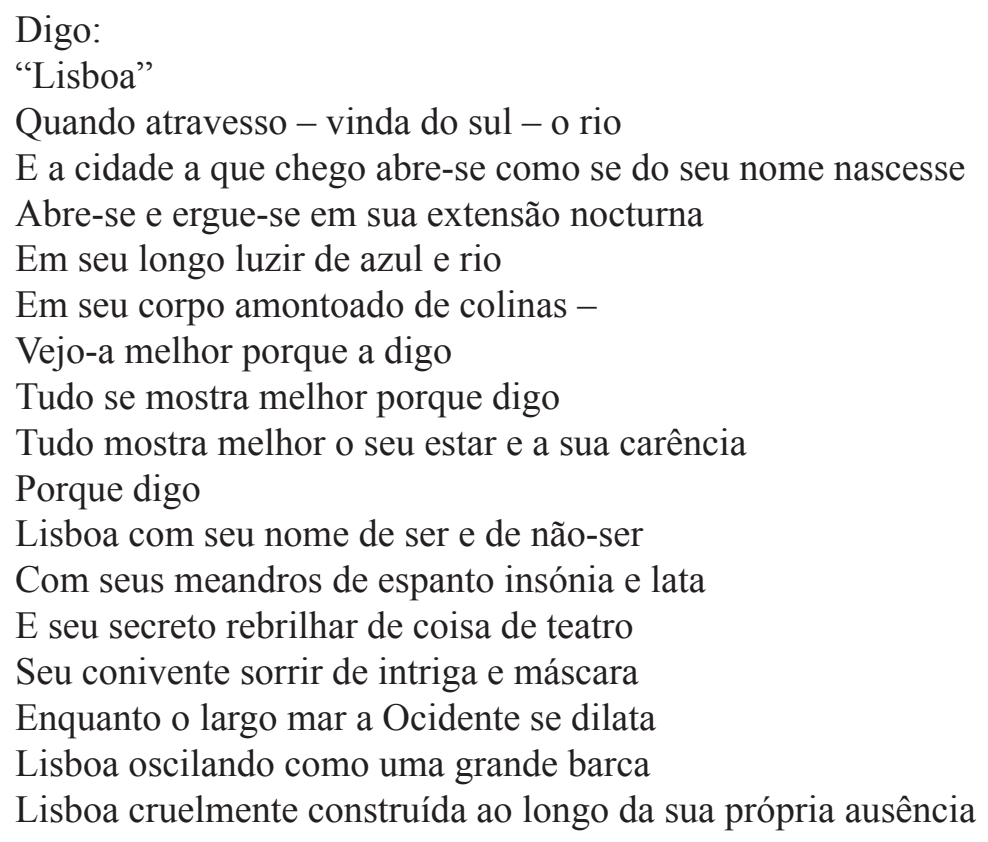

2 Informação fornecida/pensada por Jorge Fernandes da Silveira, na data da apresentação deste trabalho à disciplina que por ele é ministrada "O Retorno do Épico V". 4 jun. 2013. 
Digo o nome da cidade

- Digo para ver

(ANDRESEN, 1983, p. s/n.)

Na elaboração deste ensaio, me deparei com duas leituras distintas acerca deste poema e proponho uma terceira via complementar, como se notará a seguir. De um lado, Virgínia Boechat (2004: 12) acredita que Navegações segue um itinerário com ênfase na descoberta, no primeiro olhar sobre novos povos e mares, voltando-se também ao olhar dos que refizeram o caminho da viagem. Essa estudiosa ainda destaca que "Sophia segue o itinerário das grandes navegações, numa viagem textual que prima pela beleza e pelo espanto, com raízes, referências e surpresas” (BOECHAT, 2004, p. 13). Logo, ela sugere que Lisboa é o ponto de partida de uma viagem expansionista de um viajante que "escolhe e capta a imanência das coisas [e] descobre nossa própria existência feliz e inteira [...] e faz dessa existência deixar-se descobrir pela palavra poética" (BOECHAT, 2004, p.156).

De outro lado, Luis Maffei (2012, p. 111), advoga para o poema "Lisboa" uma indicação de um sujeito que, vindo do sul, se encontra em uma situação semelhante à do regressado após a descolonização portuguesa na África, “que não é, ressalto, um Ulisses glorioso em sua marca”. Uma situação de deriva, perda de referencial espacial, abandono.

Ao observar que "Lisboa", além de ser a capital portuguesa, local de onde partiram os primeiros argonautas lusitanos e onde se deu a Revolução dos Cravos em 1974, creio que é a cidade onde sonhos nascem e se extinguem. E, em 1977, após haver uma consciência plena de que o país estava imerso em um caos político, social, econômico (e, por que não, moral?) esse poema pode ser lido de uma terceira forma (distinta e complementar às leituras de Virginia Boechat e Luis Maffei): enquanto a revelação de um presente soturno no qual há "o seu estar e a sua carência", "com nome de ser e não ser", "seu conivente sorrir de intriga e máscara", "Lisboa oscilando como uma grande barca". Me deparo com uma urbe representada não mais como um local de onde partem naus desbravadoras de mundos e sonhos e sim uma cidade mais próxima àquela que Cesário Verde apresentara em " $\mathrm{O}$ Sentimento dum ocidental", ou seja, um local que reflete o naufrágio de uma civilização, em que vivem os órfãos do passado euforicamente expansionista: "Triste Cidade! Eu temo que me avives/ uma paixão defunta! [...]" (VERDE, 2006, p.134).

O papel do sujeito poético andreseniano nessa obra é muito mais parecido com o de Cesário Verde do que propriamente com o de um navegador sem rumo, pois o que a poeta efetivamente faz é revelar aos compatriotas a "Lisboa cruelmente construída ao longo da sua própria ausência", ou ainda, Lisboa que "Abre-se e ergue-se em sua extensão nocturna". Sublinhemos que este último verso nos revela a existência clara do elemento dionisíaco na construção de Navegações. Contrariamente ao que é dito por muitos estudiosos, quem assume a voz ativa em "Lisboa" não é Apolo e sim Dinoniso, deus da insanidade, do vinho, da intoxicação. Para Helena Malheiro (2008, p. 166), este é um deus que "[...] aparece em múltiplos poemas de Sophia, tratado de forma pouco convencional e muitas vezes disfarçado de terror e de ausência". E enquanto terror e ausência se faz "Lisboa com nome de ser e não-ser".

Cidade de "carência, "com seus meandros de espanto insónia e lata", Lisboa é retratada, revirada, observada do avesso, do adverso e é revelada a sua construção feita "ao longo de sua própria ausência". Uma ausência de perspectivas para uma população que vira seus sonhos revolucionários serem destruídos, destroçados pela ganância e mesquinhez humana.

Esse poema revela um processo de desvelamento de Lisboa e nele tanto o nomear, como algo genesíaco, quanto o ver, enquanto sentido libertador, são utilizados simultaneamente afim de contribuir para que o sujeito poemático encontre todas as verdades veladas. Sendo assim, há uma maneira grega de dizer, pois com a evocação é possível ver e ter aquilo sobre o qual se debruça. Logo, faz-se necessário que o nome da cidade seja dito - "Digo para ver" - para que o espaço físico, português, 
não saia da mente de quem parte em busca de respostas para as desgraças do presente. E isso pode ser corroborado pela própria autora ao destacar que, para ela, o tema das navegações não é apenas o feito "mas, fundamentalmente o olhar, aquilo a que os gregos chamavam aletheia, a desocultação, o descobrimento. Aquele olhar que às vezes está pintado à proa dos barcos” (ANDRESEN, 2011, p.700).

A respeito dessa “abertura" genesíaca do poema com os vocábulos "Digo/"Lisboa", Jorge Fernandes da Silveira ${ }^{3}$ argumenta que o substantivo Lisboa, ao ser grafado entre aspas no poema, remete ao fato de que a poeta evoca o que está dito acerca de tal cidade, invocando à memória deste lugar, tudo aquilo que ela possa trazer, cultural ou tragicamente. Dizer para ver e, inclusive, para terse uma identidade a se discutir. Sophia em Navegações anseia pela justeza, muito mais do que pela justiça, já que só o dizer justo reivindica a justiça no dizer.

É provável que a autora de Navegações tenha percebido o que Eduardo Lourenço ressalta quanto ao povo português ter se tornado "[...] de súbito reduzido à estreita faixa atlântica que nunca nos bastou, mas que é agora o nosso navio de regresso, encalhado à força na barra do Tejo" (LOURENÇO, 2000, p. 49). Enquanto uma tripulante desse navio encalhado que é Portugal, Sophia Andresen busca em Navegações partir psiquicamente de "Lisboa", um porto instável, em busca das nódoas, manchas que ajudem o sujeito português a refletir sobre a sua nova condição, o seu novo modo de ser e estar no mundo. Isso é bastante interessante e instigante, pois há uma busca de respostas que já foram assinaladas, assim como as armas e os barões, n’Os Lusíadas. Uma vez que havia, na partida das naus camonianas, um velho sábio a refletir acerca do empreendimento desbravador da fé e império. Por isso, evoquemos aqui o Velho: "ó glória de mandar, ó vão cobiça/ Desta vaidade a quem chamamos Fama!/ Ó fraudulento gosto, que se atiça/ Cua aura popular, que honra se chama!” (Lus., IV, 96: 142) ou ainda “A que novos desastres determinas/ De levar estes reinos e esta gente?/ Que perigos, que mortes lhes destinas/ Debaixo dalgum nome prominente?" (Lus, 1954, IV, 97, p. 142).

Sábio e até hoje não ultrapassado, Camões, no século XVI, apontava para algo que ainda no século XX é passível de ser refletido. Por esse motivo, "Lisboa" é o ponto de partida de uma viagem (de) crescente, na qual parte-se em busca de se exporem as feridas do passado, as marcas do tempo. Este poema é o primeiro, porque contribui para que o leitor compreenda que há na capital portuguesa um "conivente sorrir de intriga e máscara". Intriga que pode remeter às traições e ciladas que os lusitanos traçaram para si mesmos ao longo dos séculos, inclusive no que diz respeito à criação de um imaginário de grandeza que é falaz. Nesse processo de dissimulação, o sujeito poético revela que há uma máscara destinada a cobrir o rosto, a qual esse sujeito quer retirar, desvelando, assim, o lado oculto de Lisboa.

Dando continuidade à viagem empreendida em Navegações, nos deparamos com a segunda parte dessa obra, "As ilhas". Esta pode ser relacionada, em algumas passagens, à invocação épica, uma vez que a poeta invoca aquilo que lhe inspirará ou auxiliará na escrita árdua do poema, como observa-se nas seguintes estrofes do poema "I": “[...]/Era de um verde espesso e sonolento//Um ver imóvel sob nenhum vento/Até à branca praia cor de rosas/Tocada pelas águas transparentes”(ANDRESEN, 1983, p. $\mathrm{s} / \mathrm{n})$.

Ao debruçar-me mais cuidadosamente sobre os versos acima destacados, percebo uma invocação a Os Lusíadas camonianos. Principalmente, no último verso, que evoca "E vós Tágides minhas pois criado/Tendes em mim um novo engenho ardente/ [...] Porque de vossas águas Febo ordene/ que não tenham inveja às de Hipocrene" (Lus, 1954, I, 4, p. 18). "Tocada pelas águas transparentes" é uma maneira da poeta tocar a sua fonte de Hipocrene, de inspirar o fazer poético que se alevanta.

Ainda no poema "I" de "As Ilhas", há uma espécie de fiat lux a balizar o nascimento e o sentido épico do poema. Tal sentido dá-se também no primeiro verso: ao ser demarcado o sujeito coletivo

3 Informação oral fornecida por Jorge Fernandes da Silveira, na data da apresentação deste trabalho à disciplina que por ele é ministrada “O Retorno do Épico V”. 4 jun. 2013. 
que fala "Navegámos para o oriente". O verbo navegar aparece no primeiro verso de três poemas dessa segunda parte da obra, no poema "I" conjugado "Navegamos", no poema "II": "Navegação", e no poema "VI": "Navegavam". Note-se que há, nas três formas da palavra navegar uma progressão em que o sujeito coletivo "nós" - figuração do sujeito poético e de seus contemporâneos - passa para uma zona neutra "navegação", até o regresso àqueles que desbravaram os mares "navegavam". Essas mudanças podem indicar um afastamento progressivo do poema em relação àquele que o canta, tornando a viagem presente um mergulho no passado em busca de respostas ou mais questionamentos a fim de vislumbrar o presente.

No último verso do poema "I" há uma afirmação um tanto quanto enigmática "E extinguiram-se em nós memória e tempo". Diante de "um azul tão puro e tão violento" o sujeito lírico vê-se sem visão, cego, uma cegueira que faz com que o tempo e a memória extingam-se para, a partir de então, poder ser esquecido o maravilhamento diante das navegações e possa ser vislumbrado o seu lado oculto. O sol negro surgido nas navegações, aos poucos, vai clareando, e na extinção do tempo, o mito esvai-se, pois o cantar elaborado por Sophia Andresen, em Navegações é o tempo do mito. Logo, para chegar-se a respostas para os problemas do presente é necessário o sacrifício do mito, seja ele o da criação - Ulisses - o mito Camoniano, ou o de D. Sebastião, ou ainda a própria literatura que carrega consigo esse interstício entre o mítico e o histórico.

O poema "VI" é sintomático quanto a essa espreita ao passado, pois traz consigo o espanto pela coragem dos navegadores e a transitoriedade histórica e identitária que ali teve início:

Navegavam sem o mapa que faziam

(Atrás deixando conluios e conversas

Intrigas surdas de bordéis e paços)

Os homens sábios tinham concluído

Que só podia haver o já sabido:

Para a frente era só o inavegável

Sob o clamor de um sol inabitável

(ANDRESEN, 1983, p. s/n.).

Espantosamente amedrontador é o primeiro verso deste poema, "Navegavam sem o mapa que faziam", pois sugere coragem, força, luta, sem deixar de lado a morte, o medo e certa obrigação a que os navegantes se viam presos: a obrigação de servir ao rei. Isso se torna um tanto quanto visível, contemporaneamente, por sabermos que nenhum rei construiu a história, desbravou mares ou foi destemido. Todos eles, no fim das contas, utilizavam-se dos vassalos que possuíam para, cada vez mais, aumentarem suas terras, impérios, fé. Ou seja, com este intuito megalomaníaco, as realezas portuguesas causaram aquilo que é assinalado por Fernando Pessoa em "Mar Portuguez": “Ó Mar salgado, quanto do teu sal/ São Lágrimas de Portugal/ Por te cruzarmos quantas mães choraram/ Quantos filhos em vão rezaram!/Quantas noivas ficaram por casar/ Para que foste nosso, ó mar" (PESSOA, 1965, p. 82).

Acaso alguma vez o mar chegou mesmo a ser português? Fernando Pessoa, Camões e Sophia colocam esse questionamento em xeque, ao demonstrarem em mais de uma vez a sapiência quanto à transitoriedade marítima. E enquanto ambiente transitório, o mar é afeito a mudanças, não só em si mesmo, mas também no tocante às terras que banha, que beija, com as quais se envolve. E isso é o que Sophia aponta ao dizer que "Os homens sábios já haviam concluído/ Que só podia haver o já sabido:/ Para frente era só o inavegável/ Sob o clamor de um sol inabitável”. Sábios como o Velho camoniano, possuidores de um conhecimento que não deveria ser duvidado, olvidável. E como é dito no poema "V", que também faz parte de "Ilhas": "Ali vimos a veemência do visível/O aparecer total exposto inteiro/E aquilo que nem sequer ousáramos sonhar/Era o verdadeiro" (ANDRESEN, 1983, p. s/n.). 
Eis mais uma pergunta desconcertante a partir da leitura do poema "V": como os portugueses responsáveis pelas navegações não ousaram sonhar? Não existiram sonhos relacionados a riquezas, terras novas, exploração dos povos tidos como infiéis? Responder negativamente a esse questionamento seria subestimar aqueles que lutaram nas cruzadas e que já tinham um comércio estabelecido com o Oriente.

As navegações surgiram a fim de encontrar uma rota marítima para o oriente, nasceram do desejo cobiçoso e vaidoso de um rei que encontrou em seus súditos uma correspondência direta quanto a esses sentimentos. Portanto, o que foi descoberto pelo sujeito poético não foram riquezas, mas provavelmente sentimentos, respostas, questionamentos novos que "nem sequer ousáramos sonhar", levando-o mais perto de desvendar um dentre muitos porquês de seu país estar, quase cinco séculos depois das viagens expansionistas, imerso em um caos que essas mesmas excursões contribuíram para fazê-lo submergir.

Se ali depararam-se com a "veemência do visível", o ardor desse encontro foi muito mais do que prazeroso, foi duro, áspero, árido e vil. E dessa maneira, nesse encontro, o eu lírico andreseniano encontra mais uma parte daquilo que buscou ao deixar Lisboa: "O aparecer total exposto inteiro". Curioso é que em um dos poemas constituintes dessa segunda parte da obra, poema "VII", há o sentimento de medo sublinhado, a saber: "Difícil é saber de frente a tua morte/E não te esperar nunca mais nos espelhos da bruma”(ANDRESEN, 1983, p. s/n). O que pode ser difícil nesse caso ( e nessa leitura) é saber-se diante da morte de valores e ideias cristalizadas pelo imaginário cultural e mítico português, como é o caso da grandeza que acreditam envolver as navegações marítimas dos séculos XV e XVI. Por esse motivo, essa dificuldade se estende também à perda de uma aura misteriosa e fantasiosa (mítica), dentro da qual vive ainda hoje D. Sebastião.

A própria Sophia (2011, p. 676), em uma nota, diz que "O poema VII é um poema a D. Sebastião". Ou seja, extinguir o mito torna-se uma tarefa dolorosa, pois, com ele se esvai toda uma crença na esperança de salvação que viria de um lugar além. A partir do momento em que sabe-se que a bruma não é algo transparente e nítido, não mais esperar olhar através dos espelhos que ela forma é, de alguma forma, temer expurgar os males, revelar a falácia existente por detrás da construção de uma história calcada na invenção, na fantasia e que, paradoxalmente, a literatura busca revelar. Talvez, nesse caso, é possível pensar Navegações como uma tentativa de romper o espelho narcísico que os portugueses carregam consigo, uma vez que, de tanto viverem a história presente admirando as sombras do passado, os lusitanos acabaram por mergulhar numa fantasia.

A terceira e última parte de Navegações é chamada "Deriva". Nela nota-se uma correspondência com a "narração" épica. Como o próprio título demonstra, essa parte trata da navegação portuguesa no passado e presente. Uma navegação à deriva, sem caminhos certos, perdida no meio das tormentas ficando à mercê dos ventos, no caso da história portuguesa, à mercê das grandes potências econômicas mundiais. Por esse motivo, essa parte não aponta uma solução e sim deixa em aberto essa característica da perda do referente presente, a qual também faz com que o futuro seja ainda mais incerto.

$\mathrm{O}$ vocábulo deriva é caracterizado como um desvio causado por uma corrente ou pelo vento. Ou seja, relaciona-se à perda de controle, à perda dos desejos, à submissão do humano ao natural. E é exatamente isso que notamos num pequeno poema dessa terceira parte da obra: "Nus se banharam em grandes praias lisas/ Outros se perderam no repentino azul dos temporais". Inicialmente, é possível observar que "Nus" é a inversão da palavra "uns" e, nesse caso, é oposta a "outros". Essa inversão nos obriga a rever um lugar comum, principalmente, referente ao maravilhamento dos navegantes (do passado e do presente) frente à ação de navegar e às terras descobertas. Notemos ainda que, neste poema, a perda de controle pode ser percebida através da utilização da partícula "se" (em se perderam ou em se banharam), pois, nesse caso ela tem função apassivadora. Isto é, o sujeito poético está a referir-se a outros da terceira pessoa do plural (a ELES), de maneira oculta, que foram levados 
a banharem-se em praias lisas e muitos a se perderem no azul dos temporais e do próprio mar. A perda, nesse caso, pode ser remetida à ganância de quem arriscou tudo, inclusive a vida, em busca de tesouros ocultos. O mar, enquanto um ambiente que reflete o azul do céu, angustia e possibilita que ELES se percam, mergulhem numa imensidão infinda e infinita da qual não há mais volta.

Nesse mesmo ímpeto, o sujeito poemático profere o poema "IV" no qual o desejo de expansão, enriquecimento sucumbe diante de desconhecido: "Ele porém dobrou o cabo e não achou a Índia/E o mar o devorou com o instinto de destino que há no mar". Esse poema invoca o primeiro português a contornar o Cabo das Tormentas ou Cabo da Boa Esperança no sul da África: Bartolomeu Dias. ${ }^{4}$ Este desbravador lusitano ficou célebre por ter contornado esse famoso cabo e por ter chegado ao oceano Índico através do Atlântico. Ao contrário do que pode se pensar, o sucesso do empreendimento marítimo de Bartolomeu Dias não foi recompensado com honrarias ou títulos, como atesta o fato de ter sido ele apenas mais um navegador, sem tanto destaque, na esquadra de Pedro Álvares Cabral, em 1500. Ele que dobrou o cabo, sem chegar à Índia, foi devorado pelo mar, pelo desejo de desvendá-lo, como também pela história que o silenciou.

Entretanto, esse poema também pode remeter a muitos outros ele(s), até mesmo pelo ele-eu do poema, um alguém que apesar de dobrar o mar recôndito da memória através dos poemas em que vive, acaba sendo devorado pelo mar que, como dissemos, é um espaço transitório, instável e que, mesmo tardiamente, devolve à terra todos os dejetos, as escórias que lhe foram lançados ao longo dos anos. Esse mesmo mar é que restitui ao sujeito poético a consciência de que é necessário olvidar o divino para vencer o medo do mundo natural, fazendo com que já em Coral (1950), o eu lírico andreseniano bradasse aos ventos "Sou o único homem a bordo do meu barco/ Os outros são monstros que não falam/ Tigres e ursos que amarrei aos remos/ E o meu desprezo reina sobre o mar" (ANDRESEN, 2011, p. 231). No fim das contas, o sujeito poético parece constatar que os homens sempre se deixaram ser brinquedos nas mãos dos deuses e isso é uma das coisas que Jorge de Sena enfatiza em uma carta enviada a Sophia de seu exílio em Santa Barbara, USA, datada de 4 de dezembro de 1971:

Não é, Sophia, que o mundo não esteja cheio de deuses cruéis e sanguinários - todos o foram, e continuaram a ser hipocritamente, mesmo depois de as civilizações os terem polido e habituado a não comerem carne humana - que sempre continuaram a comer, de uma maneira ou de outra [...]. Mas deuses que não são de amor, ainda que de amor devorador e destrutivo, são uma canalha inominável [...] (ANDRESEN, SENA, 2010, p.132).

O eu lírico andreseniano presente em Navegações, toma consciência não só da limitação do humano diante do real, como também da crueldade sanguinária existente até mesmo naqueles em que acreditava estar a perfeição: os deuses

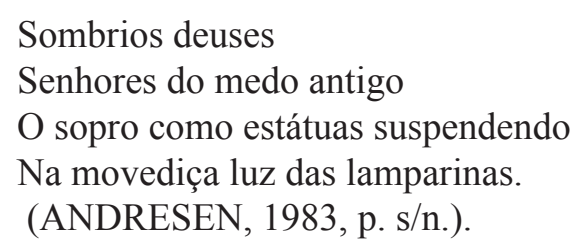

Os deuses que são causa, motivo e razão da existência de religiões e nos quais o imaginário católico português se ampara, aqui neste poema, aparecem como seres sombrios, em quem não se pode confiar, pois o medo que causam, mesmo que seja antigo, a cada momento ressurge no horizonte de um sujeito que acreditava até então na possibilidade de mudança e de plenitude que eles trariam. Pedro Eiras corrobora nossa afirmação quando destaca que em Sophia Andresen “[...] os próprios deuses, direi agora, são terríveis (cortados e cortantes): a censura que separa para sempre nautas e

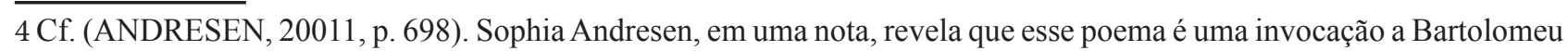
Dias. 
homines viatores de cada casa primitiva abre-se nas mãos das musas” (EIRAS, 2011, p. 29). E um dos grandes terrores do sujeito poético andreseniano não é exatamente os deuses em si, mas a percepção de que para resolver e enfrentar os problemas terrenos é necessário não mais submeter-se ao divino, e sim interrogá-lo, espreitá-lo, duvidar de sua perfeição. E isso faz com que a poeta, contra o terror da transcendência e da imanência, "assuma o terror humano, que transfigura o humano; os daimones, a loucura, a embriaguez das coisas" (EIRAS, 2011, p. 31). E o pior, assuma a loucura daqueles que saíram pelo mundo a desbravarem, a lutarem, a matarem, a morrerem, a traficarem, escravizarem, enfim a insanidade humana. Isso nos remete àquilo a que Walter Benjamin refere-se em uma das suas teses sobre o conceito de história: "Nunca houve um monumento da cultura que não fosse também um monumento de barbárie. E, assim como a cultura não é isenta de barbárie, não o é, tampouco, o processo de transmissão da cultura ” (BENJAMIM, 1994, p. 225) .

Os portugueses foram bárbaros e como tais fizeram de tudo para destituir os outros povos de sua inteireza, de sua condição humana de ser e estar privando a todos de liberdade e, o pior, o que é desvelado em Navegações, privando a eles mesmos de uma história glorificável. Como consequência, levam consigo as chagas da destruição que deixaram nos corpos humanos e terrestres de vários continentes do planeta terra. E nesse desespero de descoberta, há o canto de uma canção, poema "XIII": "Canção rente ao nada/No silêncio quieto/Da noite parada//Como quem buscasse/Seu rosto e o errasse" (ANDRESEN, 1983, p. s/n.).

Canção essa de temor e de pavor diante de uma realidade em processo de desvelamento. Uma canção de um sujeito que busca seu rosto, tentando encontrar aquilo que conhece de si ou que historicamente lhe ensinaram. Entretanto, se depara com um Outro que assusta, que lhe permite vislumbrar o lado caótico que prevalece sobre o cosmos imaginário criado em sua mente. Surge assim, um poema, último em nossa análise, que retorna ao Tejo, assim como o sujeito poético que dali não saiu um sequer momento:

\section{Inversa navegação \\ Tédio já sem Tejo \\ Cinzento hostil dos quartos \\ Ruas desoladas/Verso a verso \\ Lisboa anti-pátria da vida \\ (ANDRESEN, 1983, p. s/n.).}

É perceptível nos versos desse poema que o sujeito poemático advoga para si a capacidade ou a necessidade de fazer uma navegação "inversa", ou seja, invertida - que entre cada vez mais dentro do território conhecido a analisá-lo, a (re)descobri-lo - e/ou em verso. Esse caráter da navegação andreseniana, sublinha a necessidade de perguntar por seu rosto e remete claramente o segundo verso "Tédio já sem Tejo" ao poema de Mário de Sá-Carneiro "Eu não sou eu nem sou o outro/ Sou qualquer coisa de intermédio:/ Pilar da ponte de tédio/ Que vai de mim para o outro" (SÁ-CARNEIRO, 1995, p. 82). Essa intertextualidade com Sá-Carneiro pode ser vista como uma necessidade de buscar esse rosto, de sair do tédio que o Tejo imprime aos sujeitos e talvez como possibilidade de o poema ser essa espécie de ponte que medeia ou traz à luz o real banalizado, desesperançoso.

Esse poema dá o encerramento da minha leitura de Navegações, pois ele fecha o próprio retorno da obra sobre si mesma, ao indicar aquilo que propus no início desta leitura, ou seja, de que é uma navegação de um sujeito que partindo de Lisboa, utilizando-se dos recantos de sua memória, à mesma cidade retorna com algumas respostas, mas com muitos mais questionamentos do que imaginava encontrar, caracterizando-a como "anti-pátria da vida". Ou seja, um local que não lhe permite traçar raízes, elaborar mapas ou mesmo criar esperanças. Lisboa, em Navegações, é como Sophia disse no primeiro texto poético dessa obra, uma grande barca que oscila. Uma barca na qual todos são obrigados a adentrarem e a olharem frente a frente os seus medos e males. 


\section{Considerações finais}

Em Navegações há uma viagem psíquica e não necessariamente física, pois, nos momentos que sai do lugar físico, o sujeito jamais deixa de pensar o seu lugar socialmente construído, a sua pátria, a sua cultura e os problemas enfrentados por seu país há muitos séculos. O sujeito poético andreseniano analisado é um fado, um fardo, fadado ao desconcerto e ao descontentamento de si diante de uma realidade mundana, muitas vezes, criada, difundida a fim de acalmar os ânimos.

Essa viagem por um ambiente transitório, que é si mesmo, faz com que o sujeito olhe para a terra da qual parte, com o passado na mente, causando-lhe uma imensa angústia de viver num presente que, a cada vez que é questionado, se fratura ainda mais. Navegações é, como diz o eu lírico, uma "Navegação abstrata", através da qual busca-se, de cima, traçar-se um mapa, sem nunca obter sucesso, pois, assim como o mar, o sujeito também é transitório, sem fronteiras pré-determináveis e passíveis de serem estabelecidas.

Logo, Navegações é uma obra que estabelece um forte diálogo com Os Lusíadas de Camões, revelando, sempre que necessário, a sua filiação à grande epopeia de língua portuguesa. No entanto, enquanto Os Lusíadas é uma narrativa que cresce, sai de um ponto de partida para chegar à glória possibilitada pelos descobrimentos (mesmo acompanhada da sombra de personagens críticos como é o caso do Velho), Navegações é uma obra em (de)crescendo, partindo de si para chegar ao seu próprio interior, em busca de um autoconhecimento que só a literatura e a reflexão podem proporcionar. Cada uma dessas obras, a seu modo, contribui para que o sujeito português vislumbre a si próprio criticamente diante da realidade presente, uma vez que tanto Camões quanto Sophia trazem reflexões que são atemporais. 


\section{Referências}

ANDRESEN, Sophia de Mello Breyner. O Nome das Coisas. Lisboa: Moraes editores, 1977.

ANDRESEN, Sophia de Mello Breyner. Navegações. Lisboa: Imprensa Nacional-Casa da Moeda, 1983.

ANDRESEN, Sophia de Mello Breyner. Obra Poética. 2a ed. Alfragide: Caminho, 2011.

ANDRESEN, Sophia de Mello Breyner. Discurso proferido na premiação de "Navegações". In: Obra Poética. $2^{\text {a }}$ ed. Alfragide: Caminho, 2011, p. 699 - 700.

ANDRESEN, Sophia de Mello Breyner; SENA, Jorge de. Correspondência 1959 - 1978. $3^{\text {a }}$ ed. Lisboa: Guerra e Paz, 2010.

BENJAMIN, Walter. Magia e técnica, arte e política: ensaios sobre literatura história da cultura. $7^{\mathrm{a}}$ ed. Tradução de Sérgio Paulo Rouanet. São Paulo: Brasiliense, 1994.

BOECHAT, Virgínia Bazzetti. Na rota das navegações: Sophia de Mello Breyner Andresen. Dissertação (mestrado). Pontifícia Universidade Católica do Rio de Janeiro, Rio de Janeiro, 2004, $173 f$.

CAMÕES, Luis Vaz de. Os Lusíadas. 2a ed. Porto: Porto Editora, 1954.

EIRAS, Pedro. A face nocturna dos deuses em Sophia de Mello Breyner Andresen. Revista Colóquio/ Letras, Lisboa, $\mathrm{n}^{\circ}$ 176, 28 - 37, jan/abr, 2011.

LOURENÇO, Eduardo. O Labirinto da saudade: psicanálise mítica do destino português. Lisboa: Gradiva, 2000.

MACHADO, Rodrigo Corrêa Martins. A emergência de Abril em "O Nome das Coisas" (1977): poesia e história na obra de Sophia de Mello Breyner Andresen. Saarbrücken: Novas Edições Acadêmicas, 2014.

MAFFEI, Luis. "Em lugar de imperfeição". In: Revista Colóquio/ Letras, Lisboa, n 176, 46 - 54, jan/abr, 2012.

MALHEIRO, Helena. O enigma da Sophia: da sombra à claridade. Alfragide: Oficina do Livro, 2008.

MAXWELL, Keneth. O império derrotado: revolução e democracia em Portugal. Tradução de Laura Teixeira Motta. São Paulo: Companhia das Letras, 2006.

PESSOA, Fernando. Obra Poética. Rio de Janeiro: Nova Fronteira, 2007.

SÁ-Carneiro, Mário. Obras completas. Rio de Janeiro: Nova Aguilar, 1995.

SECCO, Lincoln. A Revolução dos Cravos e a crise do império colonial português: economias, espaços e tomadas de consciência. São Paulo: Alameda, 2004.

SILVEIRA, Jorge Fernandes da. Discurso/Desconcerto: alguns nós na literatura portuguesa. Série conferências. Vol. 8. Rio de Janeiro: Faculdade de Letras da UFRJ, 2000.

SOUSA, Sofia de Silva. "Só a arte é didática": Luís de Camões por Sophia de Mello Breyner Andresen. Floema (UESB), vol. 7, 123 - 135, 2010.

VERDE, Cesário. O sentimento dum ocidental. In: Obra poética integral de Cesário Verde (185586). Organização de Ricardo Daunt. São Paulo: Landy Editora, 2006, p. 131 - 138. 